\title{
STUDY ON THE NATURAL HISTORY OF MALARIA IN AREAS OF THE RONDONIA STATE - BRAZIL AND PROBLEMS RELATED TO ITS CONTROL
}

\author{
L.M. DEANE (1), C. DANIEL RIBEIRO (2), R. LOURENÇO DE OLIVEIRA (1), J. OLIVEIRA-FERREIRA (2) \&
} A.E. GUIMARÃES $(1)$

KEY WORDS: Malaria; Epidemiology; Rondonia State.

Studies performed more than forty years ago in the Rondonia State, as well as in other scattered localities in the Amazon Basin indicated that the only important local vector of malaria was Anopheles darlingi? - Since then, huge uncontrolled immigration, mostly from malaria free areas fion Northeastern and Southern States, has been stimulated and remarkable change in the environment has occured due to human activity, leading to a marked increase in the incidence of malaria in Brazil, reaching about 500 thousands cases in 1987, more than $40 \%$ of the patients being from Rondonia7. 9. Recent investigations in another Amazonian State (Para)', have led to the incrimination of other four anopheline species besides An. darlingi as malaria carriers by finding them naturally infected with human malaria sporozoites, but their epidemiological importance is yet to be properly assessed.

The landscape changes in several areas in the Amazon might have led to a greater contact with man of anophelme species which previousiy fed on animals which disappeared or decreased with deforestation. Are there realy other species, besides An. darlingi, which became important vectors in the Arrazon, particularly in Rondonia State, due to the changes in the environment? People, natives and immigrants, living in the endemic areas are frequenty in contact wh insod an phosnes.
How is their level of anti-sporozoite immunity? Is there a relationship between the malaria transmission rate and the degree of immunity?

To answer these questions, the most malarious Municipalities in the Rondonia State, Ariquemes and Porto Velho (capital of the State), were chosen for the implementation of a field work, which intended to determine the vector of the human malarias and their comparative importance, to study aspects of their biology which could be of help in the antimalaria program and to evaluate the degree of anti-sporozoite immunity of the local population.

The present report intends to overview our recent findings on these subjects. The original comprehensive data underlying this report will be published elsewhere.

\section{THE MOSQUITO SURVEY}

The mosquito study consisted of an anopheine survey to determine the local species, their prevalence and their natural infection rate by the two human plasmodia diagnosed in the area vivax and $\boldsymbol{P}$. falciparum. For this purpose we used an immuno-radiometric assay (IRMA) employing species specific antisporozoite monocional antibodies ${ }^{10}$, Observations on the hatits of the local species in relation to the malaria transmission were also done.

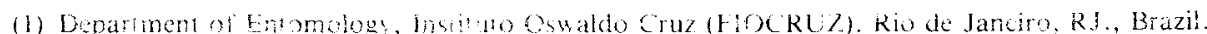

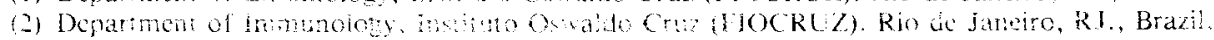

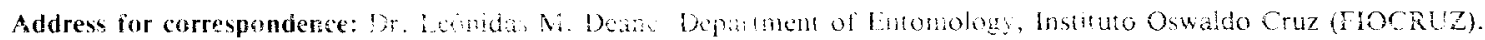

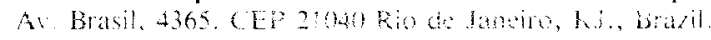


DEANE, L.M.; RIBEIRO, C.D.; LOURENÇO DE OLIVEIRA, R.; OLIVEIRA-FERREIRA, J. \& GUIMARÃES, A.E. - Study on the natural history of malaria in areas of the Rondonia State - Brazil and problems related to its control. Rev. Inst. Med. trop. São Paulo, 30(3): $153-156,1988$.

The study has been carried out since November 1985; here we shall deal with data obtained up to August 1987. Visits to the area were done trimestrally when adults and larvae of Anophelines were collected. Adult collections included captures on human bait indoors (a) and outdoors, close (b) and far (c) from the human dwellings and in the forest (d) and on animal (cow and/or horse) outdoors (e).

Captures $\mathrm{a}, \mathrm{b}, \mathrm{c}$ and $\mathrm{e}$ were performed at sunset, from 6 to 9 p.m. while captures d were carried out in three schedules: 8-10 a.m., 1-3 and 6-8 p.m. Local houses are routinely sprayed with DDT by personnel of the anti-malaria campaign. The specimens collected were kept in vials with dehydratant (silica gel) up to the identification and the IRMA tests at the laboratory.

In a total of 8071 adult females of seventeen species An. darlingi was by far the most abundant $(81.6 \%$ of the total Anophelines), followed at some distance by An. triannulatus $(5.8 \%)$, An. evansae $(3.4 \%)$, An. oswaldoi (3.2\%), An. strodei (1.5\%) and An. braziliensis $(1.4 \%)$, all remaining species being scarse: An. argirytarsis, An. albitarsis, An. galvaoi, An. nuneztovari, An. rangeli, An. benarrochi, An. mattogrossensis, An. peryassui, An. minor, An. intermedius, An. fluminensis, An. mediopunctatus, An. nimbus and $\mathrm{Ch}$. bonneae.

Inside houses, An. darlingi was found in small numbers an average of 24 specimens per 10 hours of capture, but represented $98.6 \%$ of the total anophelines. Other species were collected indoors, but with a rate lower than 0.1 per 10 hours of capture: An. albitarsis, An. galvaoi, An. benarrochi, An. strodei and An. triannulatus.

In the close vicinity of the dwellings, on human bait An. darlingi was abundant, 105 specimens per 10 hours of capture, accounting for $92.9 \%$ of the total, followed at a long distance by An. triannulatus and An. evansae (2.9 and 1.3 specimens/10 hours and 2.6 and $1.2 \%$ of the total anophelines obtained respectively). Other thirteen anopheline species were captured in this situation, always with less than 0.5 specimens per 10 hours: An. braziliensis, An. nuneztovari, An. rangeli, An. oswaldoi, An. peryassui, An. mediopunctatus and $\mathbf{C h}$. bonneae, besides the species collected indoors.

Outdoors, on human baits, far from the houses and in the forest, other species were much more numerous than An. darlingi which was the third in frequency in both situations, corresponding, respectively to 24.6 and $8.2 \%$ of the total (20.4 and 0.6 mosquitoes per 10 hours). An. triannulatus and An. oswaldoi were the most abundant species with 27.6 and 25.2 specimens per 10 hours far from houses (33.3 and $30.4 \%$ of all anophelines) and 4.1 and 2.5 mosquitoes per 10 hours in the forest (54.4 and $32.6 \%$ of the all anophelines), respectively. Other few species were scarse in these two modalities of capture, like An. fluminensis collected only in the forest $(0.7 \%$ of the total).

Either on cow or on horse placed outdoors the most varied fauna was obtained - 260.9 specimens of thirteen species were collected per 10 hours of capture, but here An. darlingi accounted for only $29.9 \%$ of the total mosquitoes and other species were also numerous: An. evansae $(17.4 \%)$, An. triannulatus $(15.1 \%)$, An. oswaldoi (10.2\%), An. strodei $(10 \%)$, followed at some distance by An. braziliensis $(7.6 \%)$, An. albitarsis $(3.5 \%)$ and An. rangeli $(2.0 \%)$, the other species being scarse.

At present, from a total of 7.686 mosquitoes of fifteen species examined by IRMA, 43, belonging to three species were positive: 37 An. darlingi, 5 An. triannulatus and 1 An. braziliensis. From these, 33 were infected with P. falciparum (32 An. darlingi + An. brazilensis and 10 with P. vivax (5 An. darlingi + 5 An. triannulatus).

Up to the last report on this subject by ourselves 6 only An. darlingi had been found infected -8 positives out of 1.327 examined.

All these species had previously been found infected in the Amazon Region: An. darlingi by several workers in different areas 1,2 , $4,5.8$, An. triannulatus by ARRUDA et al. 1 and An. braziliensis by DEANE, CAUSEY \& DEANE4. However, in Rondonia State An. darlingi should be considered the principal and primary vector of malaria, for being the most anthropophilic and abundant species, principally indoors and in the close vicinity of the dwellings and because it was the mosquito found infected in greater numbers with the two human plasmodia transmitted in the area. The importance of An. triannulatus and An. braziliensis in Rondonia still needs to be evaluated because of their exophilic and zoophilic habits according to the results presented above. 
DEANE, L.M.; RIBEIRO, C.D.; LOURENÇO DE OLIVEIRA, R.; OLIVEIRA-FERREIRA, J. \& GUIMARĀES, A.E. - Study on the natural history of malaria in areas of the Rondonia State - Brazil and problems related to its control. Rev. Inst. Med. trop. São Paulo. 30(3): 153-156, 1988.

\section{SEROLOGICAL SURVEY}

The study of the degree of anti-sporozoite immunity of the individuals was done by assessing sera for the presence of antibodies against the (NANP) + synthetic peptide by an immuno-radiometric assayı. The (NANP)4 peptide corresponds to the repetitive epitope of the CS protein of $\mathbf{P}$. falciparum sporozoitell. Sera were collected from all individuals present in each visited house in the four studied localities. Individuals were questioned about their age, approximate number of Years of Residence in the endemic region (YR) and of Past Attacks of Malaria (PAM), the use of prophylatic measures (chemoprophylaxis, repellents, mosquito nets, etc.) and other questions emphasising socio-economic aspects, all data being duly recorded. A total of 1476 sera collected from 1315 individuals have been obtained. From these 988 sera have been so far processed by the IRMA, both maies (492) and females (496) were studied.

No difference was observed in the average age between individuals from the studied localities however some differences were recorded concerning the mean numbers of PAM and YR. Individuals from Machadinho presented the highest rate of PAM $(8.3 \pm 7.8)$ followed by individuals from Cujubim (6.3 \pm 5.5), Itapoa do Oeste $(6.2 \pm 8.2)$ and Ariquemes $(5.8 \pm 7)(p<0.001$ for Machadinho vs Cujubim and for Machadinho vs Ariquemes). In the same way individuals from Itapoa do Oeste and Machadinho have been living in the area for longer periods $(7.2 \pm 7.3$ and $5.8 \pm 5.1$ YR) than those from Ariquemes and Cujubim $(4.5 \pm 5.3$ and $4.0 \pm 4.4$ YR) $(p<0.001$ for Itapoa vs Cujubim, Machadinho vs Ariquemes, Machadinho vs Cujubim and $\mathrm{p}<0.01$ for Itapoa vs Ariquemes). According to these data and to data from SUCAM (Ministry of Health) showing the very high prevalence of positive thick smears in the localities of Machadinho ( 185 positive smears per 100 inhabitants) and of Cujubim (125 positive smears per 100 inhabitants) it could be unexpected that the Machadinho inhabitants present one of the lowest percentages of individuals positive for the presence of anti-sporozoite antibodies (3.3\% comparing to $10 \%$ in Cujubim, $2.7 \%$ in Itapoa do Oeste and $4.9 \%$ in Ariquemes). Although the mean titer of anti-(NANP) $A b$ (calculated for all four localities) increased with the number of PAM ( $p<0.01$ for 9 vs 0 PAM and $\mathrm{p}<0.001$ for 9 vs 1-3 PAM), the relationship between these parameters was only evident in Ariquemes and Cujubim. These would indicate that the numbers of PAM and YR are subjective parameters to predict the degree of anti-sporozoite immunity. Indeed, recrudescence of $\mathbf{P}$. vivax malaria or of chimioresistant $\mathbf{P}$. falciparum malaria could be equivocally interpreted as new attacks of malaria induced by anopheline bites. In the same way the number of $Y R$ would reflect the degree of exposure to the risk of malaria infection only if we assume that individuals are submitted to comparable living conditions and that they are not using, at different degrees, measures of preventions such as repellents and mosquito nets. Since in the population studied here we can not exclude that these variations occur, the YR does not seem to be a very accurate parameter to evaluate the risk of exposure of individuals to the bites of infected mosquitoes. The anti-sporozoite Ab titers seem to be however related to the rate of infected Anopheles.

In fact Cujubim presented not only the highest percentage of $\mathbf{A b}$ positive individuals as well as the highest mean Ab titer but also the highest rate of anopheline carrying $\mathbf{P}$. falciparum sporozoites. The percentage of $\mathrm{Ab}$ positive individuals $2.7 \%$ in Itapoa do Oeste, $3.3 \%$ in Machadinho, $4.9 \%$ in Ariquemes and $10 \%$ in Cujubim) increased with the increasing rates of sporozoite carrying mosquitoes $(0.02 \%$ for Itapoa, 0.27 for Machadinho, 0.45 for Ariquemes and 0.88 for Cujubim). However the reasons for the discrepance between the hight rate of positive blood thick smears and the low frequency of anti-sporozoite positive and the low rate of sporozoite infected mosquitoes in some localities remain to be determined.

In summary two kinds of conclusions can be drawn, up to the moment, from the serological survey: a) In the population studied, that correspondes to migrant people from non endemic areas of malaria, more time of exposure to malaria infection and several PAM seem to be necessary for the development of anti-sporozoite immunity; and b) It seems that the development of the anti-sporozoite immunity is related to the degree of exposure of individuals to infected mosquitoes that is a reflect of the rate of infected vectors, the 
DEANE. I M.; RIBEIRO, C D.; IOURENÇO DE OLNEIRA, R.; OLIVEIRA-FERREIRA, J. \& GUIMARÃES, A.E. - Study On the naturat huscory of mataria in artas of the Rondonia State - Brazil and problems related to its control. Rev. Inst. Med. trop. São Paulo, $30,3) .153 \cdot 150,1908$

Gonity of anopheines at well as of factors that dtect this exposure such as individual presenton meatues.

\section{ACKNOWLEDGEMENTS}

We are indebt with Drs. Augostinho Cruz. Marques, João Bosco Pereira, Romeu Rodrigues Fialho, Messias Alves Rocha Souza, Valdezino Pereira de Oliveira (SUCAMMinistry of Health), Mario de Lemos Alves Filho, Percival da Costa P. Machado, Sandra Ferraciolli, Orlando Justino de Moraes (Fundação SESP) and Francisco lose de Souza UNCRA) for tacliries provided during the field work. We would also like to thank Antonio Teva, Tereza F. da Silva, Maria Monique Arle, Marcia G. de Castro, Edimilson Domingos da Silva (FrOCRUZ), José Walmir de Oliveira and Jose Roberto da Silva (Fundação SESP) for assistance in the field and laboratory work.

This study was supported by CNPG Polonoroeste, N! 70.0347/85; CNPq - PlDE VI n:s 404.063:85 (1.M. Deane) and $401.052 / 85$ (C. Daniel Ribeiro) FINEP PADCI No 43.86.0185.00 and WHO-TDR Proc. 850316.

\section{REFERENCES}

1. ARRUDA, M.E.; CARVALHO, M.; NUSSENZWEIG, R.S.; MARACIC, M.; FERREIRA, A.W. \& COCHRANE, A.H. - Potential vectors of malaria and their different susceptibility to Plasmodium falci- parum and vivax in Northern Brazil, indentified by immunoassay. Amer. J. trop. Med. Hyg., 35: 873-881, 1986.

2 DAVIS, N.C. - A note on the Malaria-carrying Anophelines in Belém, Pará and Natal, Rio Grande do Norte, Brazil. Riv. Malar. 10: 1-11, 1931.

3. DEANE, L.M. - Malaria vectors in Brazil. Mem. Inst. Oswaldo Cruz, 81 (Suppl. 2): 5-14, 1986.

4. DEANE, L.M.; CAUSEY, C.R. \& DEANE, M.P. -Nota sobre a distribuição e a biologia dos Anofelinos das Regiōes Nordestina e Amazônica do Brasil. Rev. Serv. Espec. Saúde públ. (Rio de J.), 1: 827-965, 1948.

5. GALVAO, A.L.A.; DAMASCENO, A.L. \& MARQUES, A.P. - Algumas observaçoes sobre a biologia dos Anophelinos de importância epidemiológica de Belém, Pará. Arch. Hig. (Rio de J.), 12: 51-111, 1942.

6. LOURENÇO-DE-OLIVEIRA, R.; OLIVEIRAFERREIRA, J.; GUIMARÃES, A.E.; DANIEL RIBEIRO, C, \& DEANE, L.M. - Studies in progress on malaria transmission in Rondonia State, Brazil. Mem. Inst. Oswaldo Cruz, 82 (Suppl.): PZ-29, 1987.

7. MARQUES, A.C. - Migrations and dissemination of malaria in Brazil. Mem. Inst. Oswaldo Cruz, 81 (Suppl. 2): 17-30, 1986.

8. SHANNON, R.C. - Anophelines of the Amazon Valley. Proc. entomol. Soc. Washington, 35: 117-143, 1933.

9. TAUIL, P.L. - Comments on the epidemiology and control of malaria in Brazil. Mem. Inst. Oswaldo Cruz, 81 (Suppl 2): 39-41, 1986.

10. ZAVALA, F.; GWARDZ, R.W.; COLLINS, F.H.; NUSSENZWEIG, R.S. \& NUSSENZWEIG, V. Monoclonal antibodies to circunsporozoite proteins identify especies of malaria parasites in infected mosquitoes. Nature, 299: 737-738, 1982.

11. ZAVALA, F.; TAM, J.P.; HOLLINGDALE, M.C.; COCHRANE, A.M.; QUAKYI, 1.; NUSSENZWEIG, R.S. \& NUSSENZWEIG, V. - Rationale for the development of synthetic vaccine against Plasmodium falciparum malaria. Science, 228: 1436-1440, 1985.

12. ZAVALA, F.; TAM, J.P. \& MASUDA, A. - Synthetic peptides as antigens for the detection of humoral immunity to Plasmodium falciparum sporozoites. J. Immunol. Meth., 93: 55-61, 1986. 